\title{
A influência de diferentes protocolos de jejum sobre o treinamento de força.
}

\author{
Alexandre B. Gallo*, Guilherme F. Peruca, Kellen C. C. Rodrigues, Rodrigo M. Pereira e Leandro Pereira de \\ Moura.
}

\section{Resumo}

A sarcopenia é uma doença que se faz cada vez mais presente devido aos novos estilos de vida e o aumento da população de forma gradativa, atua de forma a causar uma perda de massa magra que pode levar a disfunções metabólicas, prejudicando a mobilidade o equilibrio e a locomoção. Dessa forma o estudo visa combater essa doença através do exercício físico o qual é a melhor ferramenta não farmacológica atuando de maneira a promover as contrações musculares para que dessa forma estimule a síntese proteica, aumente o tamanho da área de secção transversa do músculo, a resistência, a força e, assim atenue a perda de massa magra no processo de envelhecimento, aliando assim o protocolo de força com diferentes protocolos de jejum.

Palavras-chave: Jejum, Exercício de força, Sarcopenia.

\section{Introdução}

O exercício físico atua em relação a sarcopenia de maneira a promover contrações musculares, estimulando a síntese proteica, aumentando assim a área de secção transversa do músculo, resistência e força, assim atenuando a perda de massa magra no processo de envelhecimento(1-2). Já o jejum promove benefícios na via de sinalização da insulina e aumento da secreção do hormônio do crescimento além de que a restrição de energia promove aumento dos níveis de glicogênio(3). No entanto não se sabe se a junçaõ desses dois protocolos se otimizam. Diante disso, este projeto avaliou os efeitos agudos de três protocolos gradativos de jejum no desempenho do exercício de força de camundongos C57BL/6J.

\section{Resultados e Discussão}
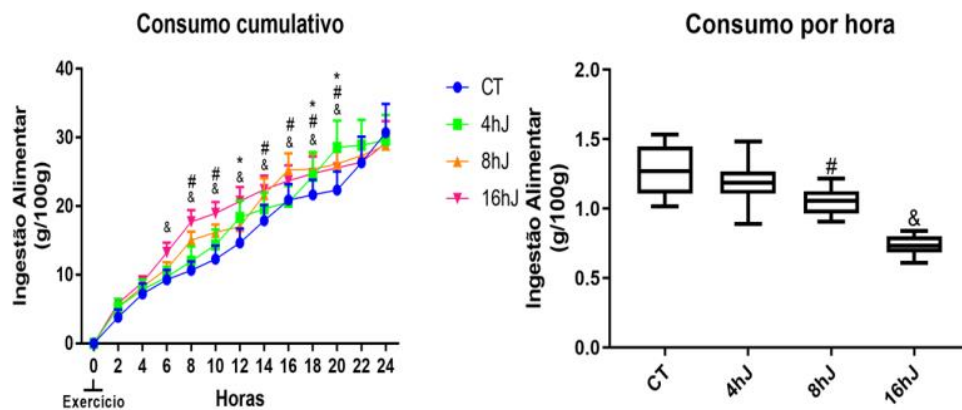

Figura 1. Dados de Consumo

\section{Consumo por período}

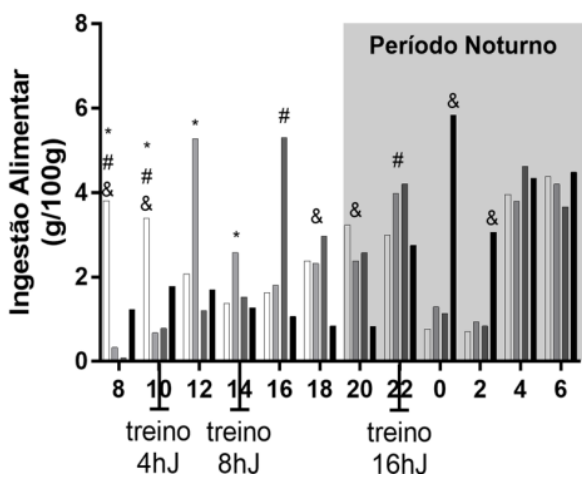

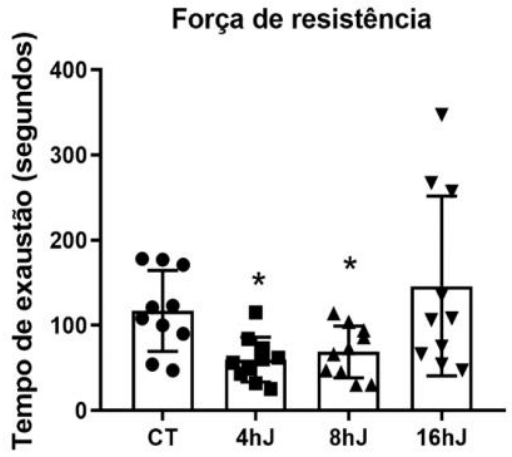

Figura 3. Dados do Teste de resistência

\section{Conclusões}

O protocolo de jejum aliado ao treinamento de força atuou de forma positiva em relação ao teste de resistência, de forma a promover um aumento de performance do grupo $16 \mathrm{HJ}$ em relação aos grupos $4 \mathrm{HJ} \mathrm{E} 8 \mathrm{HJ}$. Outro ponto importante é o de que houve redução na ingestão alimentar do grupo $16 \mathrm{HJ}$ em relação aos outros grupos no entanto não houve perca de performance indo assim de acordo com a hipótese de que a restrição alimentar não prejudicaria o desempenho dos animais e que o jejum aliado ao protocolo de treinamento de força aumentaria a performance.

\section{Agradecimentos

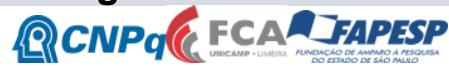

1. Glass DJ. Skeletal muscle hypertrophy and atrophy signaling pathways. Int J Biochem Cell Biol [Internet]. 2005 Oct [cited 2018 Apr 14];37(10):1974-84. Available from: http://www.ncbi.nlm.nih.gov/pubmed/16087388

2. Hawley JA, Hargreaves M, Joyner MJ, Zierath JR. Integrative biology of exercise. Cell [Internet]. 2014 Nov 6 [cited 2018 Apr 14];159(4):738-49. Available from: http://www.ncbi.nlm.nih.gov/pubmed/25417152

3. Pedrosa RG, Tirapegui J, Rogero MM, Castro IA de, Pires IS de O, Oliveira AAM de. Influência do exercício físico na composição química da massa corporal magra de ratos submetidos à restrição alimentar. Rev Bras Ciências Farm [Internet]. 2004 Mar [cited 2018 Apr 24];40(1):27-34. Available from: http://www.scielo.br/scielo.php?script=sci_arttext\&pid=S1516$93322004000100006 \& \operatorname{lng}=$ pt\&nrm=iso\&tlng=pt

Figura 2. Dados de Consumo por período 